\title{
Preferencje polityczne młodych Polaków w 2019 roku
}

Political Preferences of Young Poles in 2019

Stowa kluczowe: demokracja, młodzież, wybory parlamentarne, preferencje polityczne, poglady polityczne

Keywords: democracy, youth, parliamentary elections, political preferences, political views

Abstrakt: Artykuł jest kluczem do zrozumienia politycznych postaw i wyborów młodych Polakóww roku, wktórym odbyty się wybory do Parlamentu Europejskiegooraz do Sejmu i Senatu. Tak zdefiniowany cel zdeterminował wybór metody i techniki badawczej w duchu paradygmatu neopozytywistycznego tj. badania ilościowego. Przeprowadzone w dniach 5-23 września 2019 r. ogólnopolskie badanie umożliwiło określenie preferencji i postaw społeczno-politycznych młodych Polaków w 2019 r. Wyniki rysuja obraz biernej grupy społecznej o niesprecyzowanych pogladach, posiadającej negatywny obraz życia politycznego i niezainteresowanej życiem politycznym.

Abstract: Thearticleis the key to understanding the political attitudes and nofyoung Poles in the year in of elections to the European Parliament, as well as to the Polish Parliament took place. The goal defined in such a way determined the choice of research method and technique in the spirit of the neopositivist paradigm, i.e. quantitative research. A nationwide survey conducted on September 5-23, 2019 allowed to determine socio-political preferences and

* ORCID ID: https://orcid.org/0000-0003-4897-8393, politolog, doradca polityczny. Działacz organizacji społecznych, koordynator projektów edukacyjnych o zasięgu ogólnopolskim, uczestnik międzynarodowych warsztatów i konferencji. W 2015 r. był współzałożycielem partii Nowoczesna. W kolejnych latach byłinicjatorem i koordynatorem kampanii społecznych o kilkunastomilionowych zasięgach w Internecie. Email: adamkadziela93@gmail.com. 
attitudes of young Poles in 2019. The results showed a picture of a passive social group with unspecified views, having a negative opinion on political life and not interested in political life.

W 1922 r.w niemieckim miesięczniku kulturalno-politycznym „Preußische Jahrbücher” ukazał się esej „Trzy czyste typy prawomocnego panowania" autorstwa Maxa Webera. W swoim dziele niemiecki socjolog i ekonomista wyróżniłmodele teoretyczne, które wskazywały źródła władzy politycznej ${ }^{1}$. Każdy z typów legitymizacji związany jest z określonym rodzajem władzy: legalnej, tradycyjnej lub charyzmatycznej2. Pierwszy typ panowania związany jest z wyznaczonymi regułami, które określają zakres kompetencyjny poszczególnych władz, a także relacje między nimi. Współcześnie występuje on w większości państw i cechuje demokratyczne reżimy polityczne. Jako drugie źródło legitymizacji władzy Weber wskazuje tradycje i zwyczaje. Władza wynikająca z tych dwóch czynników jest charakterystyczna dla monarchii i systemów, opierających się na przywilejach oraz dziedziczeniu władzy. Ostatnim wymienianym przez niemieckiego socjologa typem legitymizacji jest panowanie charyzmatyczne. Wynika ono ze szczególnych cech osobowościowych lidera politycznego, które pozwalają mu skupić na sobie uwagę ludzi, a także wzbudzić wśród nich sympatięi lojalność, a w efekcie zdobyć i utrzymać władzę. Weberowska typologia w toku rozwoju nauk społecznych została uzupełniona. Jednym z czynników legitymizujących władzę w systemie demokratycznym jest także poziom partycypacji politycznej społeczeństwa. David Beetham w kontekście legitymizacji władzy zwracał uwagę zarówno na reguły i przekonania, dzięki którym władza jest prawomocna, ale także na trzeci aspekt, związany z zachowaniami, które występują w społeczeństwie ${ }^{3}$. Legitymizacja w wymiarze zachowań zakłada przyzwolenie rządzonych na zależności władcze ${ }^{4}$. Owe zachowania dotyczą aktywnej partycypacji społeczeństwa w życiu politycznym, która przejawia się m.in. w udziale w referendach, czy wyborach. Wysoki poziom

1 M. Weber, Die drei reinen Typen der legitimen Herrschaft, Preußische Jahrbücher, 187, Berlin 1922, s. 1-12, http://dlibra.bibliotekaelblaska.pl/dlibra/docmetadata?id=47952 \&from=publication (28.12.2019).

${ }^{2}$ A. Heywood, Politologia, Warszawa 2006, s. 265.

${ }^{3}$ D. Beetham, Legitymizacja władzy, [w:] J. Szczupaczyński (red.), Władza ispołeczeństwo, Warszawa 1995, s. 288-303; T. Biernat, Legitymizacja władzy politycznej. Elementy teorii, Toruń 2000, s. 82.

${ }^{4}$ K. Jasiecki, Legitymizacja władzy iograniczenia "słabej" merytokracji, IFiS PAN, http:// www.pte.pl/pliki/2/12/Legitymizacja_i_merytokracja\%20_17.03.10.pdf (28.12.2019). 
uczestnictwa politycznego obywateli warunkuje jakość systemu politycznego. Tak rozumiany proces legitymizacji władzy jest również bliski Samuelowi Phillipsowi Huntingtonowi i Joan Marie Nelson ${ }^{5}$. Zwracają oni uwagę na konieczność uzyskania społecznej akceptacji obywateli dla reform społeczno-politycznych, by były one skuteczne i respektowane ${ }^{6}$. Z kolei Seymour Martin Lipset ${ }^{7}$ wskazuje na istniejącą korelację między poziomem partycypacji politycznej obywateli a powszechną akceptacją dla systemu demokratycznego. Warto nadmienić, że z tej perspektywy kluczowa forma partycypacji jest uczestnictwo w wyborach, szczególne znaczenie maja tu wybory parlamentarne . $^{\text {. }}$

W kontekście poziomu partycypacji politycznej społeczeństwa istotne jest podjęcie debaty związanej z kryzysem legitymizacji ${ }^{9}$. W literaturze przedmiotu wśród przyczyn kryzysu wskazuje się na: słabość elit, brak rozgraniczenia kompetencji różnych sfer przez obywateli, ale także uznawanie reguł, na których opiera się działalność państwa, zaufanie do rządzących, rozumienie mechanizmów politycznych, poziom zainteresowania polityką, samoocena kompetencji politycznych jednostek ${ }^{10}$. Czynniki te w niniejszym artykule stanowić będą przedmiot analizy w odniesieniu do grupy najmłodszych obywateli, posiadających czynne prawo wyborcze.

Wybór grupy młodych Polaków jako operat losowania motywowany jest stałą obecnością wątku preferencji politycznych ${ }^{11}$ i frekwencji wyborczej wśród młodych w debatach powyborczych. Nie bez znaczenia jest także fakt, że jednym z czynników determinujących poziom partycypacji politycznej jest wiek. Im niższy wiek wyborców tym niższy poziom partycypacji politycznej i niższy poziom legitymizacji władzy. Z kolei, im niższy jest poziom zainteresowania polityka, a także poziom rozumienia mechanizmów politycznych, tym niższy jest poziom partycypacji politycznej. Analiza frekwencji wyborczej po 1989 r. wskazuje na znacznie niższy poziom uczestnictwa młodych Polaków w wyborach względem

5 S.P.Huntington, J.M. Nelson, No Easy Choice. Political Participation in Developing Countries, Harvard University Press, Cambridge 1976, s. 2-3.

${ }^{6}$ D. Mider, Partycypacja polityczna a legitymizacja system politycznego, «Studia Politologiczne» 2010, vol. 18, s. 13.

${ }^{7}$ S.M. Lipset, Homo Politicus. Społeczne podstawy polityki, Warszawa 1995, s. 539.

${ }^{8}$ D. Mider, Partycypacja polityczna a legitymizacja system politycznego..., s. 26.

${ }^{9}$ H. Domański, Czynniki legitymizacji w 21 krajach, «Nauka» 2004, nr 4, s. 65-98.

10 Tamże, s. 69-73.

11 Na temat relacji zachodzących między wyborami a wyrażaniem preferencji politycznych zob. M. Potz, Czy wybory umożliwiają artykulacjępreferencjipolitycznych?, «Studia Politologiczne» 2015, vol. 37. 
ogółu społeczeństwa. 13 października 2019 r. odbyły się wybory parlamentarne. Wzięło w nich udział $61,74 \%$ uprawnionych do głosowania. Wśród osób od 18. do 29. roku życia frekwencja wyniosła zaledwie $46,4 \% 12$ To ważna przesłanka do podjęcia dyskusji nad przyczyną takiego stanu rzeczy. Celem niniejszej pracy jest analiza czynników, stanowiących o kryzysie legitymizacji władzy w kontekście niewielkiego poziomu partycypacji młodych Polaków. W szczególności, że problem ten dotyczy grupy 5449660 osób $^{13}$. W 2019 r. grupa ta stanowiła 14,27\% ogółu populacji.

Kluczem do zrozumienia niskiego poziomu zaangażowania młodych Polaków w życie polityczne, a co za tym idzie niskiego poziomu legitymizacji władzy, jest portret preferencji politycznych tej grupy. Lektura dostępnych badań, dotyczących preferencji politycznych Polaków pozwala na wyróżnienie istotnej luki badawczej, jaką jest brak danych i brak systematycznych badań ilościowych na grupie reprezentatywnej, które pozwoliłyby owe preferencje polityczne określić. Tak zdefiniowany problem determinuje wybór metody i techniki badawczej w duchu paradygmatu neopozytywistycznego. Analiza treści tekstów źródłowych stanowi punkt wyjścia do zaprezentowania szerokiego spektrum definicyjnego pojęć związanych z legitymizacją, partycypacją i preferencjami wyborczymi, a także umożliwia dostarczenie hipotez. Właściwą techniką badawczą jest badanie ilościowe. Przeprowadzenie ogólnopolskiego badania ilościowego, zestandaryzowane procedury badawcze i reprezentatywny dobór osób uczestniczących w badaniu umożliwia formułowanie generalizacji i weryfikację hipotez. Na podstawie przeprowadzonego w dniach 5-23 września 2019 r. przedwyborczego badania „Determinanty partycypacji wyborczej młodych Polaków” możliwe jest wyróżnienie preferencji i postaw społeczno-politycznych młodych Polaków w 2019 r. Badanie zrealizowane zostało przez Centrum Badań Marketingowych INDICATOR na zlecenie Fundacji Konrada Adenauera. Kwestionariusz badawczy został podzielony na pięć części, dotyczących danych socjodemograficznych, aktywności społeczno-politycznej, poglądów politycznych, opinii na temat procesu i aktu wyborczego, a także udziału w wyborach parlamentarnych w 2019 r. Koordynatorem projektu badawczego był Adam Kądziela. Badanie przeprowadzone metodą wspomaganych komputerowych wywiadów (CATI) obejmowało 1200 wywiadów na ogólnopolskiej

12 Badanie Ipsos dla TVP,TVN24, PolsatNews przeprowadzone w niedzielę13 października $2019 \mathrm{r}$.

13 GUS, Struktura ludności według wieku od 1970 r., http://stat.gov.pl/obszary-tematyczne/ ludnosc/ludnosc/ludnosc-piramida (28.12.2019). 
grupie osób w wieku 18-30 lat. Próba była reprezentatywna ze względu na płeć, wiek, województwo, wielkość miejsca zamieszkania. Brak w literaturze przedmiotu jednorodnej definicji młodzieży powodował konieczność zdefiniowania tej grupy. W badaniu przyjęto, że osoba młoda to osoba, która posiada prawo wybierania tj. czynne prawo wyborcze oraz nie ukończyła 30. roku życia.

Dla analizy postaw i preferencji politycznych młodych Polaków istotne jest uwzględnienie oceny własnej sytuacji materialnej przez młodzież. Bez wątpienia czynniki ekonomiczne mają wpływ na poglądy polityczne. W tym celu badanie uzupełnione zostało o pytania dotyczące aktualnego miejsca zamieszkania oraz sposobu gospodarowania dochodem. Warto w tym miejscu nadmienić, że 36,9\% ankietowanych deklaruje sięjako singiel/singielka, $35,7 \%$ zadeklarowało,żeżyje w zamkniętym związku niesformalizowanym, a 27,2\% odpowiedzi dotyczyło osób zamężnych lub żonatych. W odniesieniu do sytuacji mieszkaniowej na uwagę zasługuje fakt, że samodzielnie mieszka jedynie 28,5\% Polaków w wieku od 18. do 30. roku życia.

Wykres 1. Aktualne miejsce zamieszkania osób młodych

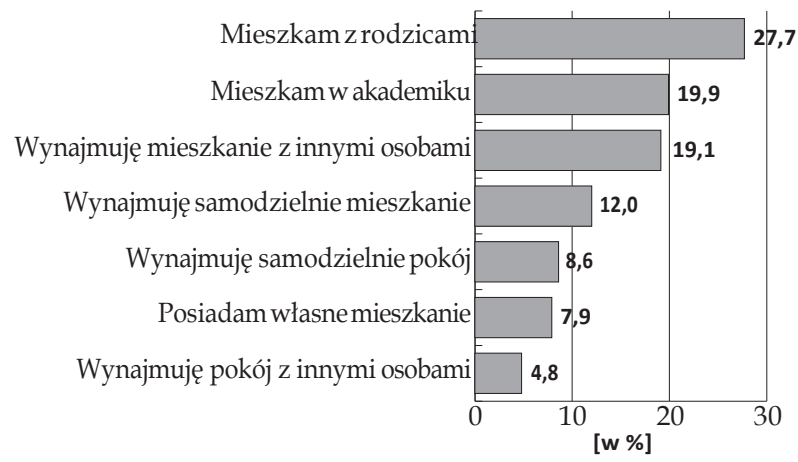

Źródło: opracowanie własne na postawie badania „Determinanty partycypacji wyborczej młodych Polaków w 2019 r.”, przeprowadzonego w dniach 5-23 września 2019 r.metodą wspomaganych komuperowych wywiadów (CATI). Badanie obejmowało 1200 wywiadów na ogólnopolskiej grupie osób w wieku 18-30 lat. Próba była reprezentatywna ze względu na płeć, wiek, województwo, wielkość miejsca zamieszkania.

Uzupełnienie powyższego wykresu stanowi ocena własnego sposobu gospodarowania dochodem. Wynika z niej, że sytuację materialną młodych Polaków można określić jako niesatysfakcjonującąich samych. Połowa młodych Polaków żyje oszczędnie lub bardzo oszczędnie, a kolejne $31,6 \%$ wskazuje, że pieniędzy nie wystarcza im nawet na najtańsze jedzenie. 
Wykres 2. Sposób gospodarowania dochodem osób młodych

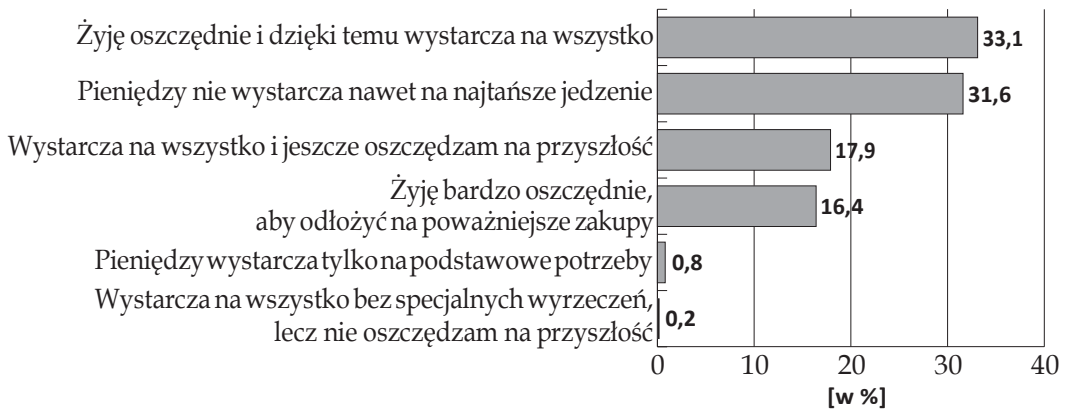

Źródło: opracowanie własne na postawie badania „Determinanty partycypacji...

Taka sytuacja mieszkaniowa i materialna młodych Polaków nie pozostaje bez wpływu na ich postawy i poglądy polityczne.

\section{Aktywność młodych Polaków}

Kolejna część badania dotyczyła aktywności społeczno-politycznej młodych Polaków. To swego rodzaju autoportret młodych Polaków. Respondenci na pięciostopniowej skali Likerta udzielali odpowiedzi na pytania związane z poziomem zaangażowania ludzi młodych w życie społeczne i polityczne. W pytaniach dotyczących formy zaangażowania wykorzystana została kafeteria, w której respondenci mieli możliwość udzielenia odpowiedzi poprzez zaznaczenie kilku opcji (pytania koniunktywne).

36,7\% młodych Polaków uważa poziom zaangażowania młodych ludzi w życie społeczne za mały lub bardzo mały. Prawie połowa uważa to zaangażowanie za średnie. Zaledwie $15,3 \%$ ocenia to zaangażowanie na dużym lub bardzo dużym poziomie.

Wykres 3. Ocena zaangażowania ludzi młodych w życie społeczne

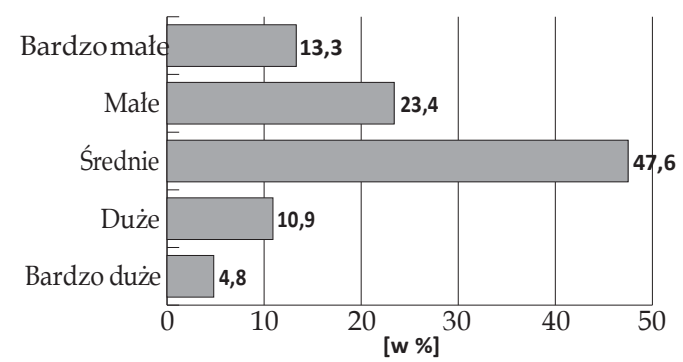

Źródło: opracowanie własne na postawie badania „Determinanty partycypacji... 
Tak krytyczną ocenę może uzasadniać niski odsetek zaangażowanych osób młodych w działania wolontariackie ${ }^{14}$. Tylko $22 \%$ osób do 25 . roku życia i 12\% osób w wieku 26-35 lat deklaruje zaangażowanie w wolontariat. Wyniki te trudno uznać za zadowalające, ale ocena ta może ulec zmianie, jeśli powyższe dane zestawione zostaną z odpowiedziami, dotyczącymi oceny zaangażowania ludzi młodych w życie polityczne. Z badania wynika, że aż 63,2\% młodych uważa poziom zaangażowania młodzieży w życie polityczne za mały lub bardzo mały. To aż 26,5 p.p. więcej niż ocena poziomu zaangażowania młodzieży w życie społeczne. Za duże lub bardzo duże uważa je zaledwie $12,7 \%$, co jest wynikiem o 2,6 p.p. niższym od oceny aktywności społecznej.

Wykres 4. Ocena zaangażowania ludzi młodych w życie polityczne

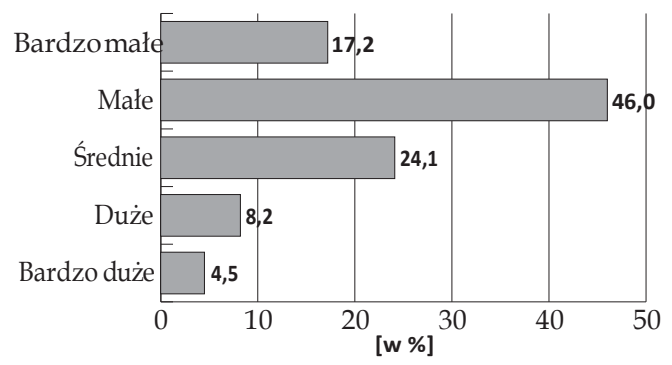

Źródło: opracowanie własne na postawie badania „Determinanty partycypacji...

W tym kontekście warto przytoczyć dane z raportu „Młodzi 2011”, które wskazują na praktyczny brak zaangażowania osób młodych w działanie partii politycznych lub organizacji harcerskich. Zaledwie 1\% osób do 30. roku życia deklaruje takąaktywność 15 . Co istotne, z badań CBOS wynika, że poziom zainteresowania polityką wśród młodych Polaków od 18. do 24. lat w latach 1989-2015 utrzymuje się na podobnym, bardzo niskimi poziomie. W ciągu tych 26 . lat odsetek osób zainteresowanych polityką w nikłym, niewielkim lub żadnym stopniu kształtował się na poziomie od $41 \%$ do $64 \%{ }^{16}$. Niski poziom zaangażowania jest jedną z przyczyn kryzysu legitymizacji władzy i, jak pokazują kolejne dane z badania „Determinanty partycypacji wyborczej młodych Polaków

14 J. Czapiński, T.Panek (red.), Diagnoza społeczna 2013, Warszawa 2013, s. 378, www. diagnoza.com (28.12.2019).

15 M. Boni, K. Szafraniec, Młodzi 2011, Kancelaria Prezesa Rady Ministrów, http://zds.kprm. gov.pl/sites/default/files/pliki/mlodzi_2011_printerfriendly.pdf, s. 283 (2.02.2020).

16 W.Kazanecki, Zainteresowanie polityka ipoglądy politycznew latach 1989-2015. Deklaracje ludzi młodych na tle ogółu badanych, Warszawa 2015, s. 4. 
w 2019 r.", nie pozostają bez wpływu na preferencje polityczne młodych Polaków.

W tej części badania respondenci zostali zapytani również o powody zaangażowania i jego braku w życie społeczne i polityczne. Odpowiedzi przybliżają główne motywy aktywności i bierności młodzieży, a także stanowią punkt wyjścia do zrozumienia postaw i poglądów politycznych najmłodszej grupy wyborców. W przypadku zaangażowania społecznego decydującymi czynnikami są czynniki o charakterze niematerialnym i altruistycznym. W największym stopniu na aktywność społeczną osób młodych wpływają wyznawane wartości $(50,2 \%)$ i poczucie odpowiedzialności (41,8\%). Warto dodać, że w kolejnych pytaniach dotyczących konkretnych aktywności społeczno-politycznych aż 76,2\% wskazań dotyczyło przekazania lub zbierania w ciągu ostatniego roku funduszy na działalnośćspołeczną. Najprawdopodobniej tak wysoki odsetek wynika z zaangażowania osób młodych w inicjatywy charytatywne ${ }^{17}$ organizowane przez Fundację Wielka Orkiestra Świątecznej Pomocy, Polski Czerwony Krzyż, czy Polską Akcję Humanitarną.

Wykres 5. Powody zaangażowania ludzi młodych w działalność społeczną

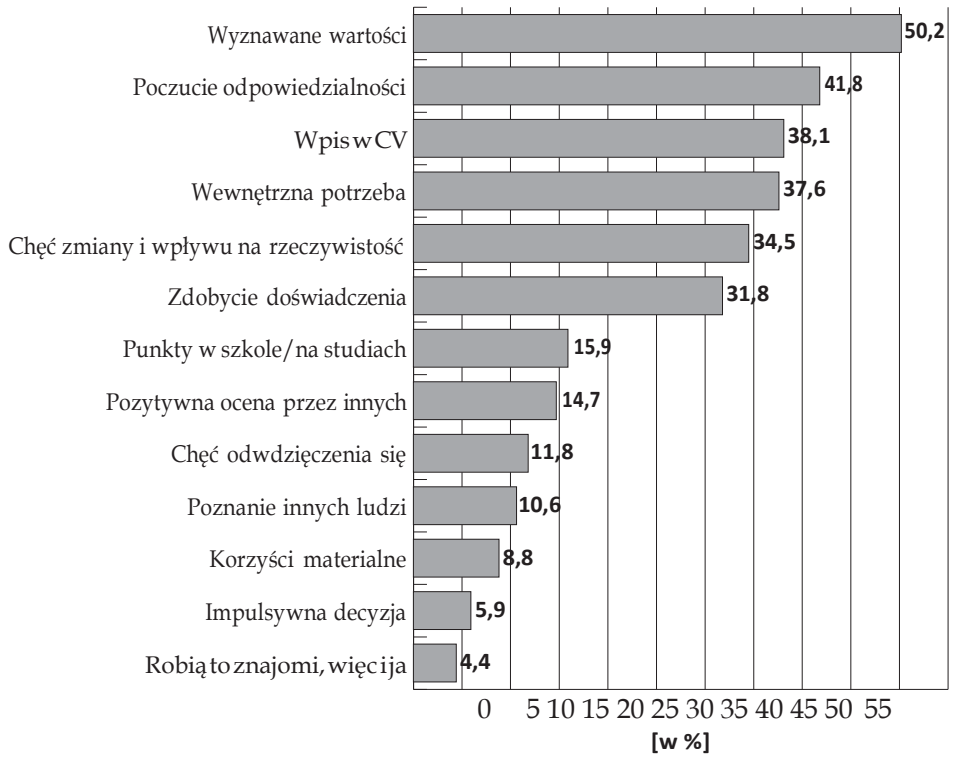

Źródło: opracowanie własne na postawie badania „Determinanty partycypacji...

${ }^{17}$ Szerzej na temat wolontariatu jako formy partycypacji społecznej zob. A. Bejma, Pojecie i klasyfikacja wolontariatu jako formy partycypacji społecznej, «Studia Politologiczne» 2010, vol. 18. 
Z kolei do głównych motywów, dla których młodzieżnie angażuje się w życie społeczne należą: brak kompetencji $(52,7 \%)$, lenistwo $(44,4 \%) \mathrm{i}$ brak czasu $(32,2 \%)$. W mniejszym stopniu decyduje o tym negatywny obraz życia publicznego (18,2\%), czy niski poziom debaty publicznej $(13,8 \%)$. To o tyle ważne, że te dwa ostatnie czynniki w największym stopniu wpływają na brak zaangażowania młodych ludzi w działalność polityczną.

Wykres 6. Powody braku zaangażowania ludzi młodych w działalność społeczną

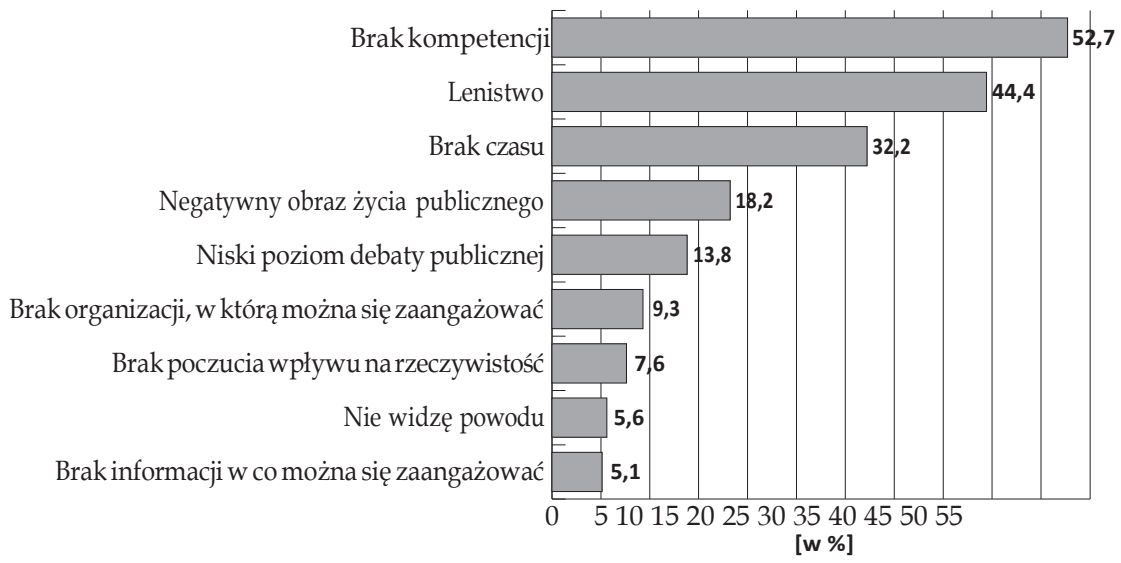

Źródło: opracowanie własne na postawie badania „Determinanty partycypacji...

Inaczej wyglądają wskazania respondentów związane z zaangażowaniem w życie polityczne. Tu decydujący wpływ mają względy pragmatyczne i materialne. Zdaniem młodych, czynnikami decydującymi o zaangażowaniu osób młodych w działalność polityczną są przede wszystkim korzyści materialne (45,7\%), chęć zdobycia doświadczenia i umiejętności $(42,4 \%)$ oraz poznanie innych ludzi $(38,1 \%)$. Odpowiedzi na temat konkretnych aktywności politycznych, które podjęły osoby młode w ciągu ostatniego roku wskazują, że zaledwie 13,9\% młodych Polaków podpisało petycję, 13,4\% brało udziałw dyskusjach w Internecie na tematy polityczne, a 5,4\% wzięło udział w demonstracji. Tylko 0,4\% wskazańdotyczyło przekazania pieniędzy lub zbiórki funduszy na działalność polityczną. To o tyle ciekawe, że podobną aktywność względem aktywności społecznej zadeklarowało aż 76,2\%.

Wśród głównych powodów, które wpływająna brakzaangażowania młodych w życie polityczne wymieniane są: negatywny obraz życia politycznego $(32,9 \%)$ i brak poczucia wpływu na rzeczywistość $(25,1 \%)$, a także niski poziom debaty publicznej $(23,9 \%)$. W najmniejszym stopniu na 
Wykres 7. Powody zaangażowania ludzi młodych w działalność polityczną

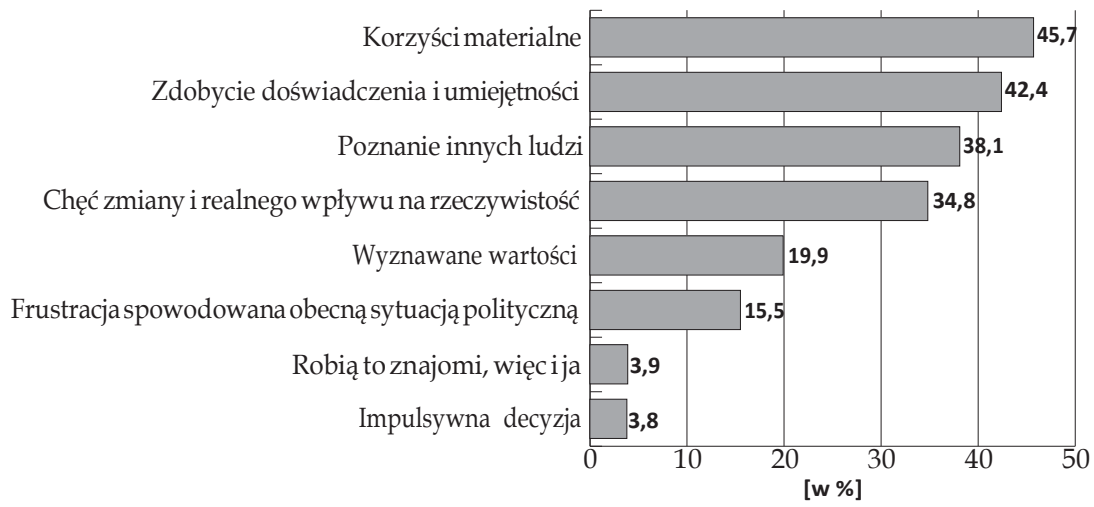

Źródło: opracowanie własne na postawie badania „Determinanty partycypacji...

brak zaangażowania wpływa brak czasu $(3,8 \%)$, brak kompetencji $(6,5 \%)$ i lenistwo $(7,5 \%)$. Warto te dane zestawić z odpowiedziami, dotyczącymi działalności społecznej. Wówczas okaże się, że trzy główne powody, dla których młodzieżnie angażuje się w życie społeczne, tj. brak kompetencji, lenistwo i brak czasu są czynnikami, które w najmniejszym stopniu wpływają na brakaktywności młodych Polaków w sferze politycznej. Tuzdecydowanie ważniejsze są kwestie związane z krytycznym podejściem osób młodych do polityki, polityków i jakości debaty publicznej. Takie postrzeganie życia politycznego wpływa także na bardzo wysoki poziom braku zainteresowania polityką. Aż 90,7\% młodych respondentów oceniło własny poziom zainteresowania polityką za mały $(51,9 \%)$ lub bardzo mały $(38,8 \%)$.

Wykres 8. Powody braku zaangażowania ludzi młodych w działalność polityczną

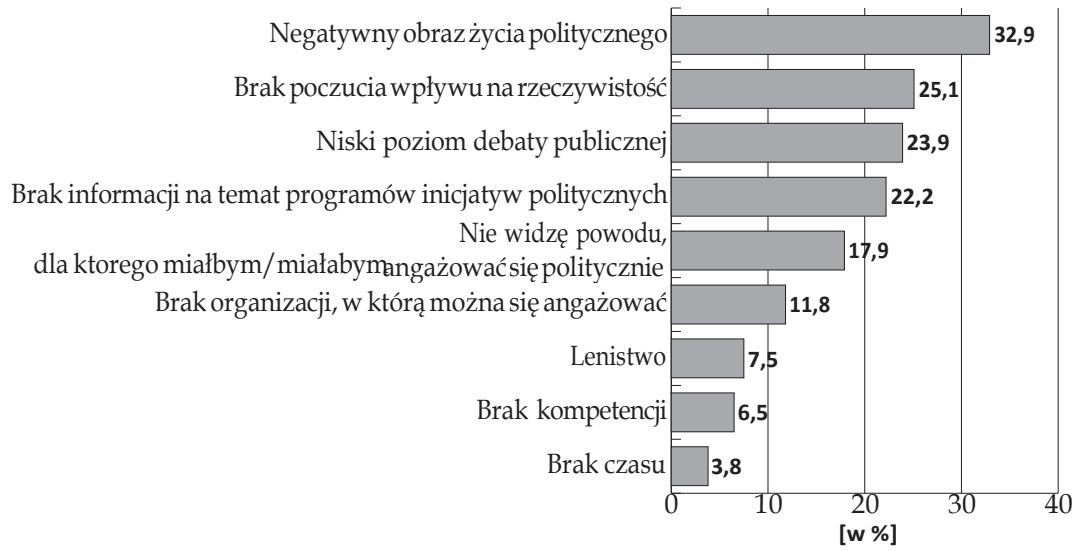

Źródło: opracowanie własne na postawie badania „Determinanty partycypacji... 
W kontekście powyższych danych, warto przeanalizować ocenę działania polityków w Polsce przez młodzież. Pozytywnie oceniło je $35,4 \%$ respondentów (zdecydowanie pozytywnie - 7,3\%, raczej pozytywnie - 28,1\%). Negatywnie zaś 63,5\% (zdecydowanie negatywnie 23,3\%, raczej negatywnie 40,2\%). Tak wysoki wskaźniknegatywnych ocen elit politycznych wpływa także na opinie, dotyczące zgodności działań polityków z oczekiwaniami młodych Polaków. Aż 74,1\% respondentów oceniło, że działania te nie są zgodne z ich oczekiwaniami. Mimo to, w tym samym badaniu aż 64,4\% pozytywnych odpowiedzi dotyczyło uwzględniania głosu obywateli przez przedstawicieli władzy ustawodawczej i wykonawczej przy podejmowaniu decyzji, które dotyczą obywateli. Jak więc wytłumaczyć ten swego rodzaju paradoks, polegający na braku satysfakcji z podejmowanych przez polityków decyzji, przy jednoczesnym przyznaniu, że w procesie decyzyjnym politycy uwzględniają opinię obywateli? Taki stan rzeczy może wynikać z postrzegania przez osoby młode procesu decyzyjnego jako procesu, w którym elementem sąkonsultacje społeczne, lecz jednocześnie pozostają one bez wpływu na ostateczne działanie polityków. Oznacza to, że samo uwzględnienie głosu obywateli nie jest tożsame z jego wpływem na finalny kształt podejmowanych decyzji.

\section{Udział w wyborach}

Kolejny obszar badania dotyczył partycypacji wyborczej młodych Polaków, ich opinii na temat aktu wyborczego oraz poglądu na udział w wyborach. 83,3\% młodych Polaków deklaruje, że bierze lub brało udział w wyborach. Jedynie 2,6\% deklaruje, że „zawsze bierze udział w wyborach". Do najważniejszych motywacji osób głosujących należą: chęć poparcia konkretnego ugrupowania $(68,7 \%)$, chęć zmiany obecnej sytuacji politycznej $(44,1 \%)$ oraz przeświadczenie o wadze pojedynczego głosu $(26,3 \%)$.

Aż 86,5\% badanych wskazało, że biorąc udział w wyborach dokonuje wyboru zgodnie ze swoimi przekonaniami i głosuje na ugrupowanie, które popiera. Z kolei 13,3\% wybiera mniejsze zło. Wśród badanych przeważało również przekonanie, że podejmowana przez nich decyzja w trakcie wyborów jest autonomiczna, niezależna od opinii rodziny, czy znajomych. W tym samym badaniu 16\% respondentów zadeklarowało, że nigdy nie chodzi na wybory. To o 14,4 p.p. więcej niż odsetek młodych osób, deklarujących, że bierze zawsze udział w wyborach. Wśród najważ- 
niejszych przyczyn braku udziału w wyborach osoby młode wskazują: brak zaufania do polityków, znudzenie polityką i układami politycznymi, a także krytyczną ocenę polityków.

Wykres 9. Powody udziału osób młodych w wyborach

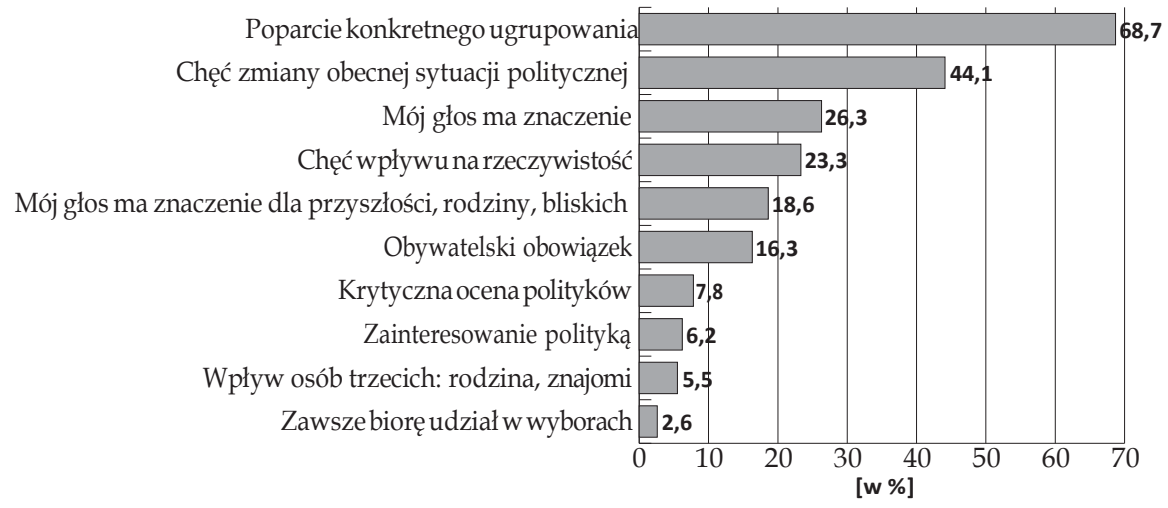

Źródło: opracowanie własne na postawie badania „Determinanty partycypacji...

Na uznanie zasługuje poziom samooceny kompetencji politycznych jednostek. Wiedza ludzi młodych na temat sposobu oddania głosu oraz miejsca lokalu wyborczego jest na bardzo wysokim poziomie. Aż 87,5\% zadeklarowało, że sposób głosowania w wyborach parlamentarnych jest prosty lub bardzo prosty. Wiedzę o lokalizacji właściwego lokal wyborczego posiada aż 98,8\% młodych wyborców. Pozytywnym aspektem badania jest również przeświadczenie ponad 85-procentowej grupy osób młodych o tym, że głosowanie to obowiązek każdego obywatela. Z tym stwierdzeniem nie zgodziło się niespełna $2 \%$ badanych. 0 tym, że trzeba chodzić na wybory, bo każdy wyborca nawet w niewielkim stopniu, ale wpływa na sytuację w kraju, jest przekonanych 82,9\% respondentów. Podobny odsetek uważa, że głos w wyborach ma znaczenie. Przeciwnego zdania jest $16,8 \%$ badanych.

Powyższe dane rysują pozytywny obraz stanu wiedzy młodych Polaków na temat wyborów. Budujące jest także przekonanie młodzieży o wadze pojedynczego głosu. Należy jednak pamiętać, że to stanowiska deklaratywne. Podobnie jest z odpowiedziami, dotyczącymi udziału w wyborach parlamentarnych.

Chęć oddania głosu w październikowych wyborach zadeklarowało aż 62,2\% młodych wyborców. Tymczasem, z przeprowadzonego przez 
pracownię IPSOS badania late poll wynika, że frekwencja wśród osób od 18. do 29. roku życia wyniosła zaledwie $46,4 \% 18$, czyli o 15,8 p.p. mniej od wcześniejszych deklaracji. Warto w tym miejscu poddać analizie preferencje polityczne młodych Polaków w wyborach parlamentarnych, które odbyły się 13 października 2019 r.

Wykres 10. Deklarowany udział w wyborach parlamentarnych 13 października $2019 \mathrm{r}$.

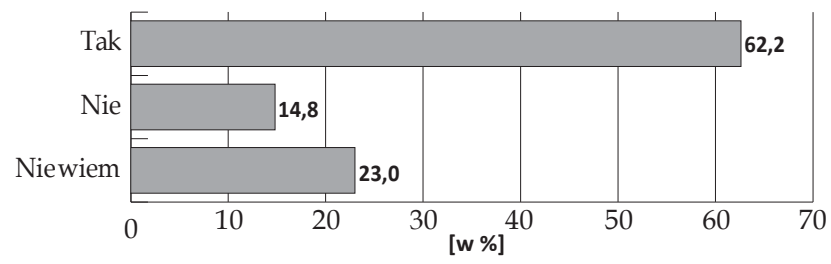

Źródło: opracowanie własne na postawie badania „Determinanty partycypacji...

Wykres 11. Wyniki wyborów parlamentarnych z dnia 13 października 2019 r.wśród osób w wieku 18-29 lat

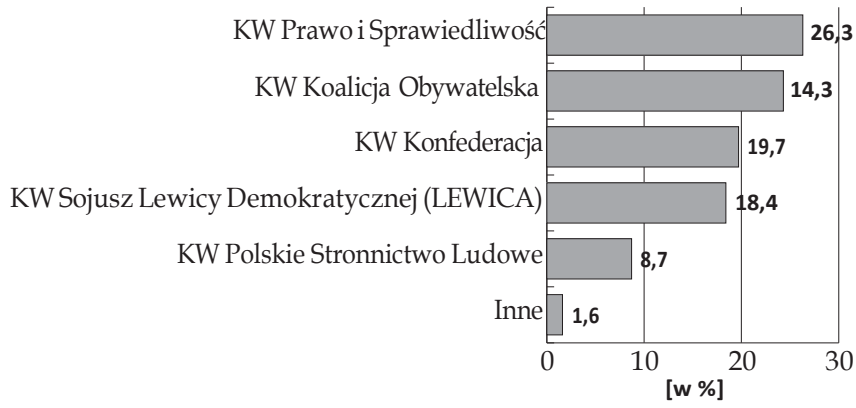

Źródło: opracowanie własne na postawie badania „Determinanty partycypacji...

W badaniu late poll autorstwa IPSOS nie widać znacznych różnic w wyrażanym przez młodych Polaków poparciu różnych komitetów wyborczych. Z danych Państwowej Komisji Wyborczej wynika, że dysproporcje te są znacznie większe wśród ogółu wyborców.

18 Badanie Ipsos dla TVP, TVN24, Polsat News przeprowadzone w niedzielę 13 października 2019 r., https://tvn24.pl/wybory-parlamentarne-2019/wiadomosci-wyborcze,474/ wybory-parlamentarne-2019-wyniki-sondazowe-jak-glosowali-mlodzi,977132.html (28.12.2019). 
Tabela 1. Wynik wyborczy Komitetów Wyborczych w 2019 r.a wynik wyborczy w grupie wiekowej 18-29 lat

\begin{tabular}{|l|c|c|}
\hline \multicolumn{1}{|c|}{ Komitet Wyborczy } & $\begin{array}{c}\text { Wynik wyborczy } \\
{[\%]}\end{array}$ & $\begin{array}{c}\text { Wynik wyborczy } \\
\text { w grupie wiekowej } \\
\text { 18-29 lat } \\
\text { [\%] }\end{array}$ \\
\hline Prawo i Sprawiedliwość & 43,59 & 26,3 \\
\hline Koalicja Obywatelska & 27,40 & 24,3 \\
\hline Konfederacja & 6,81 & 19,7 \\
\hline Sojusz Lewicy Demokratycznej (LEWICA) & 12,56 & 18,4 \\
\hline Polskie Stronnictwo Ludowe & 8,55 & 8,7 \\
\hline
\end{tabular}

Źródło: PKW, Ipsos dla TVP, TVN24, Polsat News.

Dane dotyczące poparcia poszczególnych ugrupowań wśród ogółu głosujących oraz najmłodszych wyborców wskazują na relatywnie większą popularność Komitetu Wyborczego Konfederacja i Komitetu Wyborczego Sojusz Lewicy Demokratycznej Lewica. Konfederacja zdobyła aż 12,89 p.p. większe poparcie wśród młodych niż wśród ogółu głosującej populacji. Z kolei Sojusz Lewicy Demokratycznej (LEWICA) uzyskał poparcie o 5,84 p.p. większe wśród wyborców w wieku 18-29 lat. Nieznaczny wzrost w najmłodszej grupie względem ogółu głosujących osób odnotowało Polskie Stronnictwo Ludowe. Pozostałe komitety tj. Prawo i Sprawiedliwość oraz Koalicja Obywatelska odnotowały niższy poziom poparcia wśród młodych. To odpowiednio wyniki niższe o 17,29 p.p. oraz 3,1 p.p. Czy taki rozkład poparcia jest zgodny z poglądami politycznymi wyrażanymi przez najmłodszych wyborców? Kluczem do odpowiedzi jest poznanie opinii młodych Polaków na tematy społeczne i gospodarcze.

\section{Poglądy polityczne}

W kolejnej części badania „Determinanty partycypacji wyborczej młodych Polaków" przedmiotem analizy były kwestie związane z deklarowanymi poglądami politycznym młodzieży, ich stosunkiem do religii, a także najważniejszymi problemami społecznymi i gospodarczymi, które ich zdaniem powinny być rozwiązane przez rząd. Jak się okazuje, aż ponad $60 \%$ deklaruje, że ich poglądy polityczne nie są sprecyzowane. 
Wykres 12. Deklarowane poglądy polityczne młodych Polaków

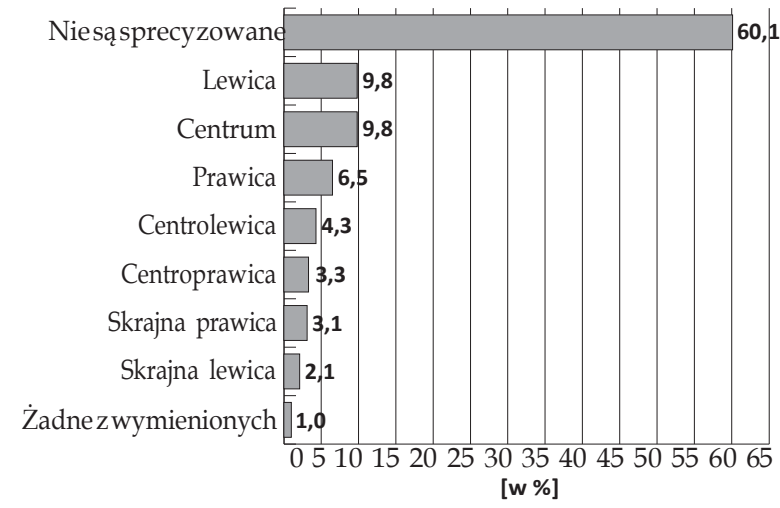

Źródło: opracowanie własne na postawie badania „Determinanty partycypacji...

Obecne w debacie publicznej opinie o skrajnie prawicowych lubskrajnie lewicowych poglądach młodych Polaków nie znajdują potwierdzenia w deklaracjach osób młodych w niniejszym badaniu. W zdecydowanej większości nie potrafią oni zidentyfikować swoich poglądów na osi lewica-prawica. Być może niedoskonałość pytania polega na zbyt daleko idącym uproszczeniu, dlatego do zrozumienia preferencji politycznych młodzieży konieczne jest poznanie jej opinii na tematy społecznogospodarcze. Prawie co piąty (18,2\%) przedstawiciel młodego pokolenia uważa, że państwo powinno być zaangażowane światopoglądowo (ideologicznie lub religijnie). Dla większości tj. 58,2\% respondentów większą wartość ma państwo neutralne światopoglądowo. Dla większości $(60,3 \%)$ osób młodych równie ważne są wolnośćobyczajowa i gospodarcza. Dla $14,3 \%$ respondentów ważniejsza jest wolność gospodarcza od wolności obyczajowej. Z kolei 9,5\% wskazało wolność obyczajową nad gospodarczą. Co ciekawe, z badania wynika także, że aż 96,8\% badanych zadeklarowało się jako osoby wierzące. Do grupy osób „wierzących i praktykujących” zaliczyło siebie 44,9\% W kontekście tych wyników ciekawie prezentują się poglądy osób młodych na kwestie społeczne.

Na pytanie o najważniejsze problemy społeczne, które powinien rozwiązać przyszły rząd najwięcej odpowiedzi dotyczyło kwestii równouprawnienia płci $(70,3 \%)$, neutralnego światopoglądowo państwa $(49,3 \%)$, powszechnego i bezpłatnego dostępu do edukacji przedszkolnej (37,8\%), a także rejestracji związków partnerskich $(34,1 \%)$. Z kolei co piąte wskazanie dotyczyło legalizacji aborcji i eutanazji na życzenie.

W odniesieniu do problemów gospodarczych najwięcej wskazań dotyczyło kwestii socjalnych. Największa grupa osób do najważniejszych 
Wykres 13. Najważniejsze problemy społeczne, które powinny być rozwiązane przez rząd w opinii młodych Polaków

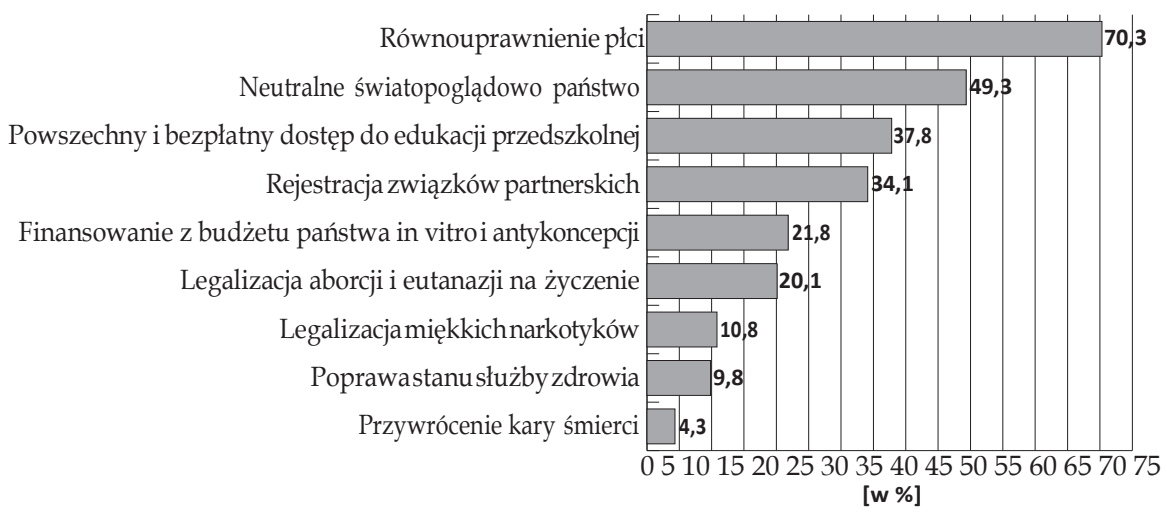

Źródło: opracowanie własne na postawie badania „Determinanty partycypacji...

Wykres 14. Najważniejsze problemy gospodarcze, które powinny być rozwiązane przez rząd w opinii młodych Polaków

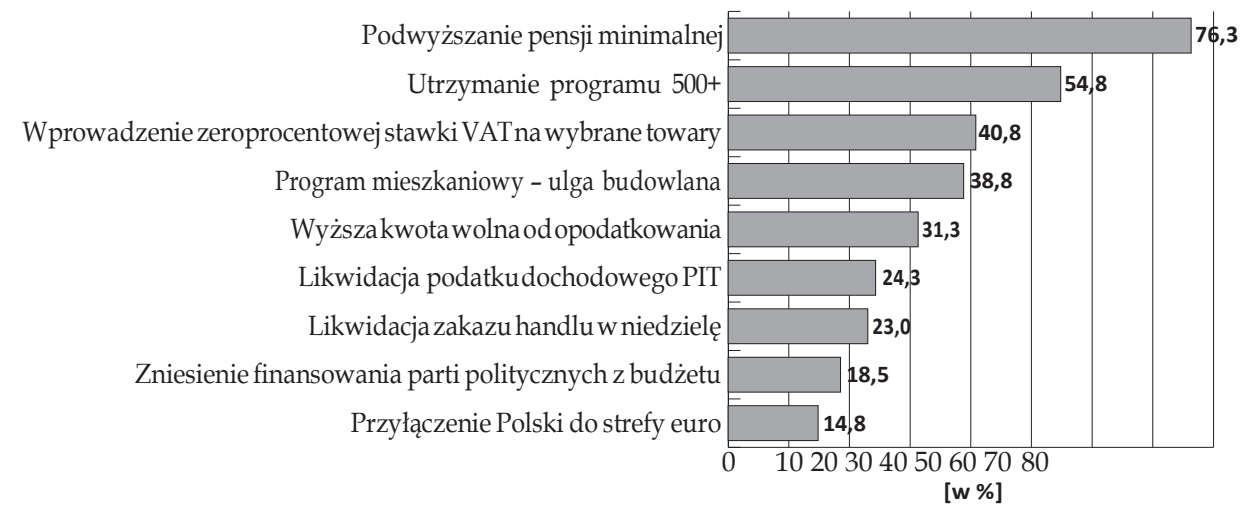

Źródło: opracowanie własne na postawie badania „Determinanty partycypacji...

problemów gospodarczych, które powinien rozwiązać przyszły rząd zaliczyła kwestie podwyższenia pensji minimalnej (76,3\%), utrzymania programu $500+(54,8 \%)$, wprowadzenia zeroprocentowej stawki VAT na niektóre produkty $(40,8 \%)$ oraz programu mieszkaniowego $(38,8 \%)$. Tylko co czwarte (23\%) wskazanie dotyczyło kwestii zakazu handlu w niedzielę. Kluczem do zrozumienia powyższych wskazań mogą okazać się dane dotyczące sytuacji ekonomicznej młodych Polaków. 


\section{Wnioski}

- Analiza różnych form partycypacji politycznej młodych Polaków, począwszy od poziomu zaangażowania społeczno-politycznego, poprzez poziom zainteresowania polityką i udział w wyborach jest tożsama z niskim poziomem legitymizacji władzy wśród młodych Polaków.

- Potwierdzeniem niskiego poziomu legitymizacji jest znacznie niższy (o 17,29 p.p.) poziom poparcia dla rządzącej partii wśród najmłodszych wyborców w porównaniu do wyniku wśród ogółu wyborców.

- W kontekście trwającej debaty związanej z kryzysem legitymizacji istotne jest wskazanie na wyłaniający się z badań krytyczny stosunek młodych Polaków do elit, brak zaufania do rządzących oraz niski poziomu zainteresowania polityką.

- Na uwagę zasługuje wysoki poziom kompetencji politycznych jednostek (związany z wiedzą nt. sposobu oddania głosu oraz miejsca, w którym znajduje się lokal wyborczy), a także silne przeświadczenie o wadze pojedynczego głosu i znaczeniu wyborów.

- Obecne w debacie publicznej opinie o skrajnie prawicowych lub skrajnie lewicowych poglądach młodych Polaków nie znajdują potwierdzenia w deklaracjach osób młodych. Zdecydowana większośćnie posiada sprecyzowanych poglądów politycznych.

- Dla większości osób młodych równie ważne są: wolnośćobyczajowa i wolność gospodarcza.

- Wśród najważniejszych kwestii społecznych młodzi Polacy wyróżniają równouprawnienie płci, neutralne światopoglądowo państwo, powszechny i bezpłatny dostęp do edukacji przedszkolnej oraz rejestrację związków partnerskich.

- Do najważniejszych kwestii gospodarczych młodzieżzalicza podwyższenie pensji minimalnej, utrzymanie programu 500+, wprowadzenie zeroprocentowej stawki VAT na niektóre produkty oraz program mieszkaniowy.

\section{Bibliografia}

D. Beetham, Legitymizacja władzy, [w:] J. Szczupaczyński (red.), Władza i społeczeństwo, Warszawa 1995.

A. Bejma, Pojęcie iklasyfikacja wolontariatu jako formy partycypacji społecznej, «Studia Politologiczne» 2010, vol. 18.

T. Biernat, Legitymizacja władzy politycznej. Elementy teorii, Toruń 2000. 
J. Czapiński, T. Panek (red.), Diagnoza społeczna 2013, Rada Monitoringu Społecznego, Warszawa 2013, www.diagnoza.com (28.12.2019).

H. Domański, Czynniki legitymizacji w 21 krajach, «Nauka» 2004, nr 4.

S.P. Huntington, J.M. Nelson, No Easy Choice. Political Participation in Developing Coun- tries, Harvard University Press, Cambridge1976.

K. Jasiecki, Legitymizacja władzy i ograniczenia "słabej" merytokracji, IFiS PAN, http://www. pte.pl/pliki/2/12/Legitymizacja_i_merytokracja\%20_17.03.10.pdf (28.12.2019).

W. Kazanecki, Zainteresowanie polityka i poglądy polityczne w latach 1989-2015. Deklaracje ludzi młodych na tle ogółu badanych, Warszawa 2015.

D. Mider, Partycypacja polityczna a legitymizacja system politycznego, «Studia Politologiczne» 2010, vol. 18.

M. Potz, Czy wybory umoźliwiaja artykulację preferencji politycznych?, «Studia Politologiczne» 2015, vol. 37. 